and beliefs, with particular reference to the worship of the god Kungwe. Films were taken of various aspects of Mahili village life and tape recordings made of songs, musical instruments, drumming, dances, and speech of the Holoholo.

\title{
A Bibliography of the Belgian Congo
}

A BIBLIOGRAPHY of historical, ethnographic, and linguistic studies, at present lodged in the archives at Léopoldville, has recently been prepared by the Section Documentation of the Secrétariat Général. It is entitled Documents pour servir à la connaissance des populations du Congo Belge and is the second in the series Archives du Congo Belge. The majority of the studies listed are unpublished reports made in the course of administrative duties, but when they have been published, references are given wherever it has been possible to trace them. The first part of the volume consists of a general historical survey of the studies made from r886-1933. The second part lists them under classificatory headings-ethnographic, geographical, linguistic, \&c.-and by Provinces : ethnographic and linguistic maps are listed separately. The index contains names of authors, places, tribes, and languages, and there are fourteen Appendixes giving the text of the official instructions relating to the study of the Belgian Congo peoples.

\section{International Bibliography of Social and Cultural Anthropology}

THE second volume of this bibliography, consisting of works published in 1956 , has just been published by UNESCO. It has been compiled according to the principles laid down in the first volume, which appeared in 1958, but the number of periodicals analysed has been increased and the subject index considerably developed.

\section{$V$ isit of S. P. Smirnov to the Sudan Republic ${ }^{1}$}

S. P. Smirnov, of the Akademia Nauk S.S.S.R., Moscow, visited the Sudan Republic in April last year to collect material for a history of the Sudan and to meet Sudanese historians. He went to the Gezira, Bad Medani, Sennar, and Port Sudan. He noted that the Beja, who live on the outskirts of Port Sudan, while undertaking casual labour, continue to keep cattle and preserve their tribal traditions. He considers that a single Sudanese nation is rapidly emerging in the Northern Sudan.

\section{Conference Organized by the Rhodes-Livingstone Institute, February I9s9}

THE Rhodes-Livingstone Institute holds frequent conferences on various aspects of its research in the social field, for discussion among interested research workers, administrators, and others, of topics of mutual interest. It is hoped that such conferences are of indirect use for governments and similar bodies in providing information, besides being sources of ideas for research projects.

The $x_{3}$ th of these conferences was held at the Institute's headquarters at Lusaka from ro to I $_{3}$ February 1959, on the adaptation of indigenous African political systems to the situation arising from the establishment of modern systems of government. After a general discussion of some Western policies in Africa, political adaptation was examined in the Belgian administered territory of Ruanda, among the Luvale, the Soli, and the Nsenga of Northern Rhodesia, among the Ibo of Western Nigeria, in Nyasaland, in Tanganyika, and in Somalia. The speakers on these societies were, respectively, Professor Maquet, C. M. N. White, W. J. Argyle, R. J. Apthorpe, A. H. St. John-Wood, D. G. Bettison, R. L. Wishlade, H. A. Fosbrooke, and I. M. Lewis. The main speakers explaining government policies were Roger Howman, Esq., Under-Secretary, the Division of African Affairs, the Government of

'Abridged by M. H. from S. P. Smirnov, 'Poezda v respubliku Sudan' ('A visit to the Sudan Republic'), Sovietskaia etnografia, 1958, no. 6, pp. I12-20, Akademia Nauk S.S.S.R., Moscow, 1958. 